Maria Bloch-Trojnar

Department of Celtic

John Paul II Catholic University of Lublin

Al. Racławickie 14, 20-950 Lublin, Poland

bloch@kul.lublin.pl

\title{
SELECTED ASPECTS OF THE SYNTAX AND SEMANTICS OF DE-VERBAL NOMINALISATIONS IN ENGLISH, POLISH AND IRISH
}

\section{0 . Introduction}

Bearing in mind the formal complexity and functional versatility of the category of verbal nouns in Irish (henceforth VNs), it is not surprising that it continues to be the subject of intensive research. Much has been written on the syntax of VNs proper (Ó hAnluain 1999), i.e. VNs employed in participle and infinitive constructions, and linguists are so absorbed in the debate about whether to regard them as nouns or verbs ${ }^{1}$ that the area of deverbal nominalisations has not received due attention. This paper is meant as a modest attempt to amend this situation and present some aspects of their syntax, semantics and formal derivation. This paper is both empirically and theoretically oriented. A presentation of various views on de-verbal nominalisations in English and Polish will set the scene for the discussion of the Irish material. It will be demonstrated that Irish de-verbal nominalisations share certain characteristics with both of these languages.

\section{De-verbal nominalisations in English and Polish}

The inception of morphology as an independent field in modern linguistics has its roots in Chomsky's (1970) "Remarks on nominalisation" and English de-verbal nominals have henceforth served as a testing ground for various theoretical models. In this paper we shall argue in favour of the

${ }^{1}$ McCloskey (1983) and Duffield (1995) are representatives of the two opposing views. Ó hAnluain (1999), who makes a distinction between VNs proper (ainm briathartha ceart) which function as both nouns and verbs, and VNs which have the same form as the VN proper, but which behave like ordinary nouns (gnáth-ainmfhocal), admits that it may sometimes be difficult to draw a definite dividing line between the two groups. Also an attempt at delimiting various verbal and nominal categories was made in Bloch-Trojnar (2006). 
framework of Lexeme Morpheme Base Morphology (LMBM) and subsequently apply it to the analysis of our data.

\subsection{Previous approaches}

As action nominals are cross-linguistically regarded as categorical hybrids (Koptjevskaja-Tamm 1993) most studies of nominalisations recognise and attempt to come to grips with the process/result dichotomy. ${ }^{2}$ Nominalisations exhibit actional (verbal) semantics and non-actional readings which envisage the existence of "something material connected with the verbal idea (agent, instrument, belongings, place or the like)" (Marchand 1969: 303). This semantic ambiguity is crucially interlocked with the number of accompanying satellite phrases. In English, the behaviour of nominalisations with Latinate suffixes, -ing and zero derivatives are recurrent and contentious issues which have spawned abundant literature. $^{3}$

In traditional accounts of nominalisation it is assumed that there is one process with regular semantics which yields derivatives denoting '(act)ion' or 'process of Verb-ing' (Bauer 1983, Szymanek 1989). Malicka-Kleparska (1988) advocates the view that concrete nominals are not derived productively by Word Formation Rules (WFRs). She treats them as offshoots of lexicalisation phenomena that affect corresponding formally identical actional nominalisations. ${ }^{4}$ Cetnarowska (1993) incorporates zero derivatives within the same pattern because they show both regular actional meanings and similar lexicalised senses.

Another strain of research relates the semantico-syntactic properties of nominalisations to differences in terms of inheritance of thematic grids from the verbal base (Ranadall 1984, 1988, Roeper 1987, Williams 1981, Grimshaw 1990) and consequently two distinct lexical rules are proposed.

\footnotetext{
${ }^{2}$ Anderson (1984) introduces the distinction between - concrete and abstract nouns, Malicka-Kleparska (1988) - regular nominalisations and lexicalisations, Walińska (1984) - clausal nominals with a full $\Theta$-grid and $\Theta$-nominals.

${ }^{3}$ A full exposition and evaluation thereof lies beyond the scope of this paper. A concise and comprehensive review of various approaches to nominalisation (the Configurational Hypothesis, the Event Structure theory, Neo-transformationalist accounts) is offered in Rozwadowska (1997).

${ }^{4}$ Walińska (1984) introduces the distinction between clausal nominals with a full $\Theta$-grid and $\Theta$-nominals. In the lexical process one of the argument positions is incorporated in the meaning of the resulting nominal and becomes the external $R$ (referential) theta role of the noun.
} 


\subsection{Two Word-Formation Rules}

\subsubsection{Grimshaw (1990) and Event Structure theory}

Grimshaw (1990) introduces a distinction between complex event nominals (CE nominals) with an associated argument structure and simple event or result nominals which lack it. In the former (some of) the participants in the activities or states described by the verb, which are part of its lexicosemantic representation (LCS), are projected into an a-structure representation, i.e. they stand in a grammatically significant relationship to predicates. The latter do not have a-structure as part of their lexical representation though they may have semantic arguments in their LCS definitions realised as complements and modifiers. ${ }^{5}$ Grimshaw (1990) extends the notions of internal and external arguments, which are standard GB labels for obligatory NPs accompanying verbal predicates, to the analysis of CE nominalisations and observes that in contradistinction to verbs, in nominalisations the external argument is optional. If the external argument is present (either as a NP in the genitive case or a by-PP), the internal argument is obligatory. Only the subject-like by-phrases and pre-nominal genitives requiring the presence of an object NP are licensed in a-structure.

(The enemy's) destruction of the city

The destruction of the city (by the enemy)

It is assumed that there exists a non-thematic argument $R$ which serves as an external argument for nouns and hence appears with simple event and result nominals. $E v$ is integrated into the argument structure of verbs and occurs in the argument structure of complex event nominals (Williams 1981, di Sciullo and Williams 1987, Higginbotham 1985).

Gerundive nominals possess all properties typical of complex event nominals, i.e. they allow only the definite determiner thus precluding the indefinite article, the demonstrative or pronominal 'one', never pluralise and never occur predicatively:

The shooting of rabbits is illegal.

${ }^{*}$ A/one/that shooting of rabbits is illegal.

${ }^{*}$ The shootings of rabbits are illegal.

*That was the shooting of rabbits.

Consequently, they will be specified for Ev. Affixes like -ation, -ment, etc. are ambiguously specified as introducing either $E v$ or $R$.

\footnotetext{
${ }^{5}$ Modifiers modify whatever the noun denotes, e.g. fohn's dog (fohn is not in any way part of the meaning of $d o g$ ). They are simply related to the $R$ argument in the LCS representation, while complements are LCS arguments. Complements obey selection, and modifiers occur predictively.
} 
(3)

\author{
shooting $\mathrm{N},(\mathrm{Ev}(\mathrm{x}(\mathrm{y})))$ \\ observation $\mathrm{N},(\mathrm{Ev}(\mathrm{x}(\mathrm{y})))$ \\ observation $\mathrm{N},(\mathrm{R})$
}

Up to this point the two approaches are in agreement, because CE nominals correspond to regularly derived nominalisations in traditional approaches whereas result nominals correspond to lexicalised forms. However, according to Grimshaw (1990) zero derivation introduces $R$ and zero-derived forms are not complex event nominals. ${ }^{6}$ Unlike -ing nominals, they can be preceded by the indefinite article or be even made plural in Light Verb Constructions (LVCs), e.g.

Let's take a walk.

They gave each other glances.

The two strains of research offer valuable insights into the nominalisation process. However, they differ in the treatment of zero-derived nominals. In what follows it will be argued that only by combining and refining them can we arrive at a comprehensive account. Namely, there are two processes, the products of which are subject to lexicalisation. Let us now substantiate the claim that there are two regular nominalising processes.

\title{
1.2.2. Zero derivation as an exponent of a regular distinct nominalising process
}

Semantic, formal and grammatical regularity (manifested in terms of possible satellite phrases) coupled with high productivity of -ing suffixation are sufficient evidence for regarding it as an exponent of a regular nominalising process. In this section we shall adduce some evidence put forward by linguists of different persuasions (Brinton 1998, Cetnarowska 1993, Beard 1995, Bloch-Trojnar 2007) for a similar treatment of zero derivatives.

Brinton (1998) investigates "the aspectual effects of deverbalising devices", i.e. the mapping of aktionsart properties of a verb to a corresponding nominalisation. Nominalisations characterised by Latinate suffixes reflect the widely acknowledged analogy ${ }^{8}$ between event verbs and count nomi-

${ }^{6}$ This representation apparently finds support in the compound system. Compounds headed by -ing nominals are typically synthetic (a god-fearing man, a fun-loving teenager (with the least prominent argument inside the compound and the most prominent outside)) whereas those headed by zero-derived forms (bee sting(s), dog bite(s)), are typically root compounds. Since they can be argument taking or not, there is ambiguity in the heads formed with affixes with -ion, -ment etc.

${ }^{7}$ For more examples see Cetnarowska (1993: 43).

${ }^{8}$ An impressive list of authors who advocate this distinction is given in Brinton (1998: 37). 
nals (perform - performance, arrive - arrival) and between state or activity verbs and mass-nominals (astonish - astonishment, guide - guidance). ${ }^{9}$ However, -ing nominals and Ø-derivatives, which feature mainly in LVCs, fail to preserve the aktionsart of the verb. Whereas the -ing suffix "has the effect of converting the situation into an activity, of making the situation durative, atelic and dynamic" (Brinton 1998: 48), conversion "is a means of converting the situation into an event (an accomplishment, achievement, or semelfactive) by adding the feature of telicity" (Brinton 1998: 50). Consequently, two distinct processes applied to verbs of all situation types are proposed.

Grimshaw (1990) regards zero derivatives as simple event nominals with no a-structure which are incapable of inheriting arguments of related verbs. Cetnarowska (1993: 71-84) investigates the inheritance of Predicate Argument Structures (PASs) in bare nominalisations outside complex predicates and concludes that it is effected in actional readings as in, e.g.

$$
\begin{aligned}
& \text { the purchase by India of howitzers from the Swedish firm of } \\
& \text { Bofors }
\end{aligned}
$$

This would imply that contrary to Grimshaw zero derivatives are ambiguous between argument-taking and non-argument taking readings just like Latinate nominalisations.

In view of the existence of actional and lexicalised senses and parallels in terms of inheritance of PASs, Cetnarowska proposes that zero derivation is co-functional with suffixation and is ordered as the last process of the block. However, subsuming zero-derivation under one nominalising process fails to capture its semantic regularity (the Nomen Acti reading 'a single instance of V-ing') and additionally its high productivity poses some problems for the operation of the mechanism of blocking (cf. BlochTrojnar 2007).

\footnotetext{
${ }^{9}$ However, it seems to escape her that suffixed forms cannot be typecast as either countable or uncountable. Due to unpredictable workings of lexicalisation, we can encounter suffixed forms that have both actional and concrete or anti-durative senses and that they are characterised by variable number. In the former meaning they are non-count nouns and correspond to atelic, durative situations. The actional meaning always goes hand in hand with uncountability, whereas the concrete reading may be associated with countable nouns (cf. Bloch-Trojnar 2007). Furthermore, for almost every count-noun there is a corresponding non-count noun but not vice-versa. Consider, e.g. performance: "N-count: a performance involves entertaining an audience by doing something such as singing, dancing or acting" Inside the theatre, they were giving a performance of Biset's Carmen..."Nuncount.: the performance of a task is the fact or action of doing it" He devoted in excess of seventy hours a week to the performance of his duties. For more examples see BlochTrojnar (2007: 51-2).
} 
To round up: zero derivatives are highly productive, they can be derived from verbs of all situation types and are capable of inheriting arguments. They introduce an element of telicity which is related to their countability. Let us now see how these facts find a unified account in the model of LMBM put forward by Beard (1995).

\subsubsection{Beard (1995)}

Beard (1995: 199) proposes that the ubiquitous process/result contrast in nominalisations can be resolved by regarding them as products of distinct lexical rules, which differentiate nominalisations in terms of their capacity for expressing number. ${ }^{10}$

The actions expressed by the nominals such as a statement, $a$ walk or $a$ swing refer to countable instances of that action. They are similar in meaning to the perfective aspect, as in has stated. The meaning of -ing nominalisations is close to that expressed by the imperfective, is stating, has been stating.

$$
\begin{aligned}
& \text { the stating (of the fact by the mayor) } \\
& \text { (John's) walking (through town) } \\
& \text { the swinging (of the bat by the player) }
\end{aligned}
$$

This is stated in crude terms, but his model seems well equipped to provide a comprehensive account of the nominalisation process. ${ }^{11}$ First of all, because it regards number as a morpholexical feature for nouns and sec-

${ }^{10}$ Beard (1982; 1995:111-115) convincingly argues that number in nouns is not syntactically determined. Firstly, according to Chomsky (1970) any process which is not fully productive and semantically regular belongs to the realm of the lexicon. Plural is characterised by formal and semantic irregularities/subregularities. There are numerous examples of formal irregularity, e.g. deer, oxen, women, lives, foci, phenomena, antennae, indices. Some nouns have lexically determined number, i.e. pluralis tantum nouns, e.g. pants, oats, pliers, and singularis tantum nouns, e.g. air, semantics, hate, pork. Secondly, in highly inflectional languages (Russian, Latin, Sanskrit) pluralisation causes a shift in paradigm. There are two separate sets of case endings: one for the singular and one for the plural. Thirdly, languages in which inflection has atrophied preserve affixation as a means of marking the plural, e.g. in Bulgarian and Hindi. In addition to this, number markings may be borrowed, which never happens to inflectional affixes, e.g. English $-i,-a$, - $a e$ or $-e s$ and no language marks number with a free morpheme. Hence number in nouns is regarded as a morpholexical feature which can be exploited in derivation. Beard (1982: 140) claims that "whether a stem is subject to formal or semantic pluralisation or singularisation is strictly a matter of the lexicon, a matter of lexemic properties".

${ }^{11}$ His idea has been taken up and argued for in Bloch-Trojnar (2007) on grounds of cognitive plausibility, cross-linguistic preponderance and most importantly the operation of the mechanism of blocking. 
Maria Bloch-Trojnar:

Selected aspects of the syntax and semantics of de-verbal nominalisations...

ondly because it endorses separationism, ${ }^{12}$ which provides a solution to the polysemy/homonymy problem with regard to affixes spelling out more than one derivational category. Following Beard, we shall postulate two word formation processes: one which yields countable nouns, and another which is responsible for the formation of uncountable nouns.

\subsubsection{The application of the theoretical tools of LMBM to English and Polish nominals}

Beard (1995: 177) defines transposition as follows: "The Lexicon may transpose any member of any major lexical class $(\mathrm{N}, \mathrm{V}, \mathrm{A})$ to any other major lexical class by providing it only with the lexical G-features of the target class and neutralising (but not deleting) the inherent features of the base". The inherent morpholexical features of verbs are Verb Class and Transitivity (information on the number and organisation of grammatical arguments related by a predicate), whereas the inherent morpholexical features for nouns are Number, Gender and Noun Class. As nouns in English do not bear morphological gender features and are not divided into arbitrary lexical classes the only feature that is available to grammatical processes of transposition is number. Count-nouns will be specified as [+Singular; -Plural] and noncount nouns as [-Singular; -Plural]. ${ }^{13}$

In regular nominalising processes the information of a-structure is preserved but neutralised, which means that verbal arguments can be realised in the complement and adjunct positions of a nominal phrase marker. ${ }^{14}$ When the complement position is occupied by the internal verbal ar-

${ }^{12}$ The theory of LMBM is laid out and argued for in Beard (1995). For a concise exposition of major tenets thereof the reader is referred to Beard and Volpe (2005). The Separation Hypothesis (Beard 1976, 1995), which is the cornerstone of the LMBM model, says that there is no direct connection between the side of morphology that deals with morphophonological operations and the side that specifies semantic-syntactic changes. Consequently, the conditions on derivation are different from the constraints on affixation.

${ }_{13}$ According to Beard count nouns are singular because they refer to one member of a set of objects, but the conceptual distinction of singular and plural is "irrelevant" as far as mass nouns are concerned. They are singular by default because the singular is the morphologically unmarked number used "where number is irrelevant or ambiguous" (Beard 1982: 144). Therefore, count-nouns and non-count nouns will be used with the morphological singular.

${ }^{14}$ The notion of "obligatoriness" came in for criticism from, e.g. Szymańska and Śpiewak (1994), who argue that it is not a syntactic criterion but the domain of the LCSrepresentation. They attempt to account for the distribution of various types of satellites with the aid of the geometry of the "tree-marker" and the Case module. The only distinction that needs to be made is that between Complements (i.e. sister(s) of the head) and Adjuncts (i.e. sisters of the X-one-bar projection of the head). NP postmodifiers in Polish receive genitive case regardless of their LCS status. They can denote possession, kinship, authorship and complementation. 
gument the result is their actional reading. However, if we realise only the head of the NP the resulting meaning can also be that of an abstract noun denoting an activity, e.g.

(the) reading (of the poem)

(the) destruction (of the city)

It is not surprising that non-count nouns which lack specification for number features (in which number is irrelevant but nevertheless present) will be more likely to display a full array of satellite phrases which correspond to verbal arguments and preserve their subcategorisation frames. They are capable of being a slavish imitation thereof. But in principle this is also possible with nominals with specified number features. They can occur with realised LCS participants with or without the inheritance of PASs of corresponding verbs as depicted in (8a) and (8b) respectively:

a. the purchase by India of howitzers from the Swedish firm of Bofors (purchase sth) a fresh look is needed at the story (look at sth)

b. my encounter with fohn (encounter s.o.) a check on the quality of all goods leaving the factory (check sth)

They can also occur without them to denote a singular entity 'a single occurrence, a specific action' (purchase). The durative, atelic reading and non-durative, telic interpretation are a by-product of the grammatical specification of number. The existence of these two processes is signalled by productive and distinct morphological markers. Number is referential only on nouns with number contrast and refers to more than one unit of whatever the noun denotes. A corollary must follow that the operation of pluralisation can apply to nominals specified as [+Singular, -Plural]. Singular nominalisations can but do not have to pluralise. ${ }^{15}$ In fact, the presence of verbal features secures that it is an infrequent operation. Unlike with lexicalised forms, which bear only nominal features.

Lexicalisation or semantic drift to which all lexical items are subject (whether simple or derived) blurs this neat picture but not beyond recognition. In this process the verbal features are deleted, nominals are viewed as

${ }^{15}$ As number in nouns is an inherent morpholexical feature, the pluralisation rule becomes an optional operation subject to performative constraints. It will apply "when the speaker wishes to refer to more than one instance of the set of objects which the lexical item in question names" (Beard 1982: 145). Countable nominalisations are semantically and formally singular and they may/but do not have to pluralise. 
objects and there is only a vague connection with the verb due to phonological shape. Non-count nouns may remain so (destruction) and may acquire a referential meaning (stuffing) or may be turned into [ +Singular, -Plural] nouns capable of pluralising (description, filling (in a tooth)). Count nouns in non-actional lexicalised meaning will refer not to actions but to entities of some sort (permit, dump).

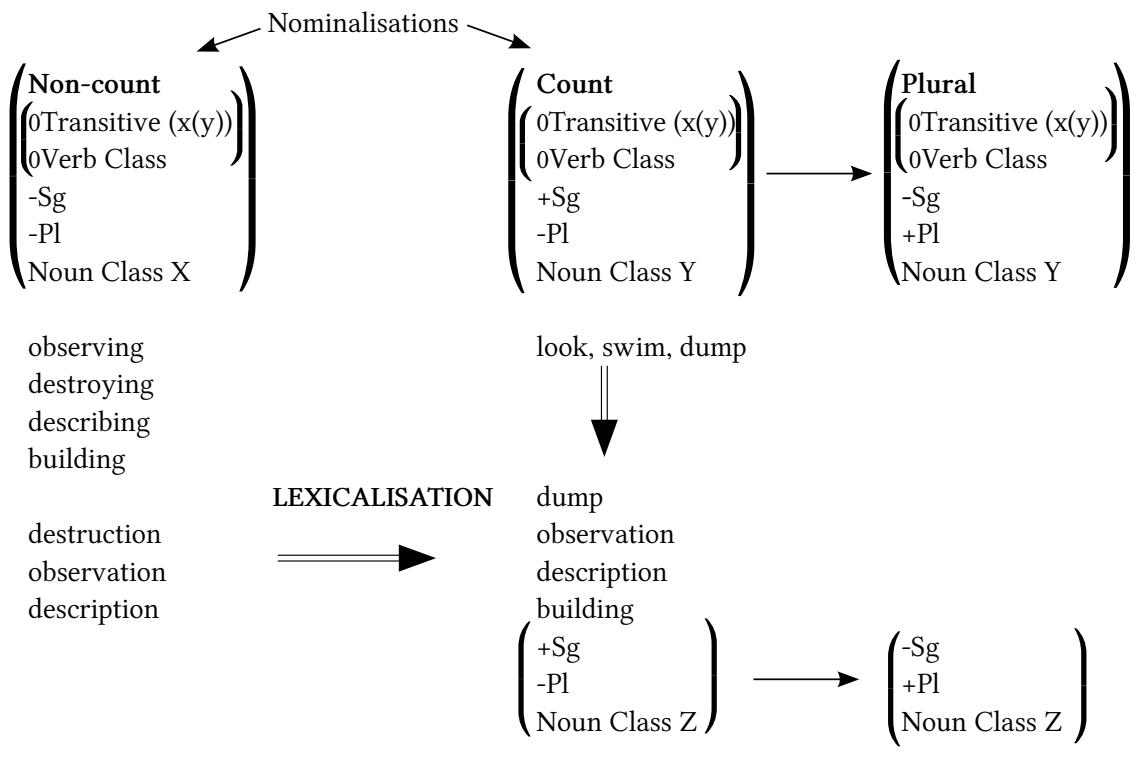

The picture that emerges is as follows: regularly formed nominalisations inherit LCS of their corresponding verbs and realise them depending on their affinity to source verbs. If their nominal (in this case number) features are irrelevant they are more like verbs. If their number features are more prominent the realisation of verbal arguments is fraught with greater difficulty. As they are morphologically singular they should be capable of pluralising, which is possible but not that frequent, because the presence of verbal features prevents their referential function. It seems that the nomenclature employed in Slavic linguistics is most adequate. Namely, a distinction is made between nomina verbalia and nomina de-verbalia, i.e. verbal nominals and de-verbal nominals (Puzynina 1969, Grzegorczykowa et al. 1999).

Let us take a look at the data from Polish to see if they can be accommodated into this picture. Verbal nominals are regular formations with -nie and -cie formatives. De-verbal nouns are marked by a plethora of suffixes varying in productivity. However, both types can be used as CE nominals which take arguments, license the przez-phrase and its presence induces 
the obligatory presence of the theme-argument. The presence of the object (as the przez-phrase is optional) is indicative of its CE status. ${ }^{16}$

(9) zniszczenie miasta przez wroga 'the destruction of the city by the enemy' sprzedaz samochodu przez fana 'the sale of the car by John'

Where there are two formations available, they could be used interchangeably.

(10) sprzedanie/ sprzedaż samochodu przez fana 'the sale of the car by John'

Both types have corresponding result nominals, which may pluralise.

Zniszczenia (" przez wroga) sq tak ogromne, że nie zdołamy ich naprawić.

'The damages (*by the enemy) are so big that we won't manage to repair them.'

Wystawitem samochód na sprzedaż ("przez fana). 'I put the car for sale ("by John).'

No replacement of sprzedaz with sprzedanie is possible in the result reading.

What matters for our discussion is that verbal nominals preserve aspectual properties of related verbs, which means that they are attested in doublets if there is a corresponding perfective/imperfective verb pair:

$\begin{array}{lll}\text { Verbs } & \text { Verbal nominals } & \text { De-verbal nominals } \\ \begin{array}{l}\text { sprzedać - sprzedawać } \\ \text { 'sell perf./imperf.' }\end{array} & \text { sprzedanie - sprzedawanie } & \text { sprzedaż } \\ \begin{array}{l}\text { ocenić - oceniać } \\ \text { 'assess perf./imperf.' }\end{array} & \text { ocenienie - ocenianie } & \text { ocena } \\ \begin{array}{l}\text { biegać } \\ \text { 'run' }\end{array} & \text { bieganie } & \text { bieg } \\ \text { obserwować } & \text { obserwowanie } & \text { obserwacja } \\ \text { 'observe' } & & \\ & & \\ & \end{array}$


Deverbal nominals such as sprzedaż, ocena or obserwacja are either neutral and their aspectual interpretation is context dependent or lexically determined (cf. Puzynina 1969). So depending on context sprzeda $\dot{z}$ could replace both sprzedanie and sprzedawanie:

$$
\begin{aligned}
& \text { Sprzedanie samochodu przez fana nastapiło bardzo szybko. } \\
& \text { 'The sale of the car by John took place immediately.' } \\
& \text { Sprzedawanie samochodu przez fana ciagnęto się tygodniami. } \\
& \text { 'The selling of the car by John lasted for weeks' } \\
& \text { Sprzedaż samochodu przez fana nastapiła bardzo szybko/ } \\
& \text { ciagnęta się tygodniami. }
\end{aligned}
$$

Verbal nominals are very close to verbs in that they preserve their aspectual characteristics, they are marked by two formatives and form nouns which are uniformly neuter in gender, obey selectional restrictions and license all verbal arguments. De-verbal nominals in process reading also preserve verbal arguments, however, they neutralise the aspectual distinction and form nouns of masculine and feminine gender. Since, Polish is a highly inflectional language number has a lesser role to play as each nominalisation process gives rise to distinct noun classes which take different inflections. Unlike their English counterparts, de-verbal nominals will not pluralise unless lexicalised ( ${ }^{*}$ sprzedaże samochodów). With these facts in mind we can proceed to the discussion of the Irish material.

\section{De-verbal Nominalisations in Irish ${ }^{17}$}

\subsection{Morphophonological exponents}

VNs in Irish are infamous for the multiplicity of formal markers. On closer inspection, it turns out that the chaos is apparent. The rules can be divided into productive and unproductive. Lexically marked items involve ca. 20 morphophonological exponents and their number approximates $c a$. 271, e.g. Ø: díol 'sell' - díol; -(e)amh [əv]: caith 'spend' - caitheamh; -í [ii]: cónaigh 'dwell'- cónaí; $\varnothing^{-\mathrm{P}}$ : cuir 'put' - cur; $-t$ [t']: bain 'cut' - baint; -chan [xən]: beoigh 'animate' - beochan; úint [u:n't']: creid 'believe' creidiúint etc. ${ }^{18}$ The regular affixation rules operate on the verbal root and

\footnotetext{
${ }_{17}$ The standard dictionary Ó Dónaill (1977) is our main source of data. However, to substantiate our argument examples are also provided from other dictionaries, grammar books, word lists and texts by writers of different dialectal background.

${ }^{18}$ For a detailed account of the morpho-phonology of VNs the reader is referred to BlochTrojnar (2006, 2008).
} 
fall into two disjunctively ordered blocks. In the first block we find three parallel rules which respond to certain phonological properties of the base, i.e. the palatalisation rule (bácáil 'bake' - bácáil), the rule of - $t$ suffixation (aifir 'rebuke' - aifirt) and the rule which leaves the verbal root intact (crúigh 'milk' - crú). In the elsewhere block we find two rules which apply to verbs belonging to a specific conjugation. The default marker of the first conjugation is -(e)adh [ə] (glan 'clean' - glanadh). Second conjugation verbs are subject to the rule attaching $-\dot{u}[\mathrm{u}]$ (maslaigh 'offend' - maslú).

\subsection{Fully-fledged nouns and their actional counterparts}

De-verbal formations, indeed, display a cluster of distributional and structural properties typical of nouns. The forms in question fill the slot of the head of an NP when they are preceded by the definite article an, modified by typical nominal modifiers, i.e. an adjective, a noun in the genitive case or a numeral as depicted in (14) below:

\begin{tabular}{|c|c|}
\hline $\begin{array}{l}\text { Tá an scrúdú thart. } \\
\text { is the examine-VN over } \\
\text { 'The exam is over.' (Ó hAnluain 1999: 198) }\end{array}$ & $\begin{array}{l}\text { luí } \quad \text { na gréine } \\
\text { go down-VN the sun-gen. } \\
\text { 'sunset' (Ó hAnluain 1999: 198) }\end{array}$ \\
\hline $\begin{array}{l}\text { hug sé amharc géar orm. } \\
\text { ve-past he look-VN sharp on-me } \\
\text { le gave me a sharp look.' (Ó Dónaill } \\
\text { 77: 40) }\end{array}$ & $\begin{array}{l}\text { an chéad léamh ar bhille } \\
\text { the first read-VN on bill } \\
\text { 'first reading of a bill' (Ó Dónail } \\
\text { 1977: 761) }\end{array}$ \\
\hline
\end{tabular}

The noun status is particularly obvious when the form in question is in the plural or is inflected for case. ${ }^{19}$

\begin{tabular}{|c|c|}
\hline $\begin{array}{l}\text { ordú béil } \\
\text { order-VN mouth-gen. } \\
\text { 'verbal order' }\end{array}$ & $\begin{array}{l}\text { Fuair mé orduithe ón rí. } \\
\text { received I order-VN-pl. from-the king } \\
\text { 'I received orders from the king.' (Ó hAnluain 1999: 198) }\end{array}$ \\
\hline & cúis ghearáin \\
\hline & $\begin{array}{l}\text { cause complain-VN-gen. } \\
\text { 'cause of complaint' (Ó Dónaill 1977: 622) }\end{array}$ \\
\hline
\end{tabular}

${ }^{19}$ Four syntactic cases are distinguished in Irish, though morphological case marking is not common within the noun itself. Morphologically, it contrasts the Common Form, corresponding to the traditional nominative, accusative, and dative cases, with a distinct marking for the genitive case. 
Nominalisations in Irish appear to tally with the traditional view in that there is a categorial process yielding nouns with the semantics 'act(ion) of Verb-ing'. They display the process/result ambiguity by means of the same set of endings. In non-actional senses nominalisations incorporate into their meaning or delete the thematic roles of the verb (cf. MalickaKleparska 1988: 67-81). This happens for example when the nominalisation denotes the result or object of V-ing, e.g.

$$
\begin{array}{ll}
\text { Verb - do sth (Theme) } & \text { Nominalisation } \\
\begin{array}{l}
\text { rud a mhíniú 'explain sth' } \\
\text { rud a cheartú 'correct sth' }
\end{array} & \text { miniú 'explanation' (Ó Dónaill 1977: 862) } \\
\text { rud a fhilleadh 'bend, fold sth' } & \text { filleadh 'bend' (Ó Dónaill 1977: 544) }
\end{array}
$$

Numerous countable nominalisations have plural forms, in which case their modification is governed by the same principles which pertain to nonderived nouns. They have little connection with their sentential analogues and their meaning becomes lexicalised, i.e. they can no longer be paraphrased as 'act(ion) of Verb-ing' and develop some specialised senses, e.g.

$$
\begin{aligned}
& \text { Verb Nominalisation (plural) } \\
& \text { oir 'suit, fit, oiriúintí oifige 'office accessories' (Ó Dónaill 1977: } 927 \text { ) } \\
& \text { wish, need' } \\
& \text { admhaigh admhálacha 'receipts' (Ó Dónaill 1977: 8) } \\
& \text { 'acknowledge' } \\
& \text { teagmhaigh teagmhálacha leictreacha 'electric contacts' (Ó Dónaill } \\
& \text { 'connect' 1977: 1216) } \\
& \text { tacair 'glean' tacair scartha 'disjoint sets' (Ó Dónaill 1977: 1190) } \\
& \text { siúl 'walk' ar mo shiúlta 'in my travels' (Ó Dónaill 1977: 1105) } \\
& \text { socraigh 'settle' socruithe sochraide 'funeral arrangements' (Ó Dónaill } \\
& \text { 1977: 1129) } \\
& \text { triail 'try, test' trialacha gunna 'gun tests' (Ó Dónaill 1977: 1270) }
\end{aligned}
$$

Doyle (2002: 100-1) observes that VNs are used as ordinary nouns to a limited extent only and that "when there is an accompanying complement, it is most unusual in the contemporary language". He provides two examples which in his opinion border on ungrammaticality:

$$
\begin{aligned}
& \text { */? Chuir briseadh na gcloch ionadh orm. } \\
& \text { put-past break-VN the stones-gen. surprise on-me }
\end{aligned}
$$

'The breaking of the stones surprised me.' 
*/? Chuala siad briseadh na gcloch.

hear-past they break-VN the stones-gen.

'They heard the breaking of the stones.'

He hypothesises that there may be some constraint in Irish "to the effect that nominalisations do not inherit the subcategorisation frames of their verbal bases" (Doyle 2002: 101). This would be tantamount to saying that there are no complex event nominals in Irish.

As far as infrequent usage of de-verbal nominals is concerned, Rozwadowska (1997: 13) notes that "nominalisations are structures that are rare in everyday conversation, especially those with a full array of satellites". According to Herbst (1988: 297) nominal phrases laden with PPs, infinitival clauses are heavy and stylistically awkward. Hence, in spoken language they are avoided and replaced with their sentential analogues. Apart from some stylistic considerations there may exist some language specific constraints. Cetnarowska (1993: 58) observes that some bare nominalisations are restricted to LVCs and are virtually unattested in the subject or subject complement position in a clause, where gerunds and action nouns in -ing are felt more appropriate, and Grimshaw (1990: 55) points out that $\mathrm{CE}$ nominals in contradistinction to result nominals are not found predicatively or with equational be, e.g.

${ }^{*}$ A clean of the lab twice a day will be your duty.

${ }^{*}$ His favourite pastime was a listen to jazz records.

That was the/an assignment vs. "That was the/an assignment of the problem.

In what follows we shall look in greater detail at the distribution and complementation of VNs in actional reading with a view to demonstrating that the Irish nominalising system is in line with what we have proposed for English and Polish in that there are both result and CE nominals and that the CE type is of two kinds, differentiated by the degree of boundedness.

\subsection{Nomina Verbalia (Uncountable nominalisations)}

Uncountable nominalisations have an actional reading and bear a striking resemblance to their corresponding verbs. They inherit the selection restrictions of their corresponding verbal bases, i.e. they denote situations involving the same type of participants. They also clearly inherit their subcategorisation frame because the direct object of the verb becomes the di- 
rect argument of the corresponding nominalisation. It can be realised syntactically as a genitive NP following the action noun as in (20a), or an NP dominated by the same preposition which the corresponding verb selects as in (20b).
a. sábháil fhéir save-VN grass-gen.
'the saving of hay'(Ó Dónaill 1977: 1018),
'haymaking' (de Bhaldraithe 1959: 329)
Cf. Shábháil siad féar. save-past they grass-acc. 'They made hay.'

b. an blaiseadh den bpágánachas Cf. Bhlaiseadar den bpágánachas. the taste-VN of-the paganism 'the experiencing of paganism' (Ó Cearúil 1999: 116) they-taste-past of-the paganism 'They experienced paganism.'

External arguments inherited from verbal bases are realised syntactically either by means of an NP dominated by the preposition $a g$, or an NP in the genitive as depicted in (21a) and (21b) respectively.
a. Bhí marú na mílte
aici.
Cf. Mharaigh sí na mílte. was kill-VN the thousands-gen. at-her 'She could kill thousands.' (Gagnepa- in 1963: 302)
b. B'é a dúirt a lán daoine.... gurbh iontach an scéalé. it-was say-VN a lot people-gen .... that-was strange the story it 'A lot of people said that it was a strange story.' (Ó Criomhthain 1997: 111)
Cf. Dúirt a lán daoine gurbh iontach an scéal é. say-past a lot people-nom. etc.
'A lot of people said that etc.'

Actional nominalisations are not often used, which can be attributed to stylistic considerations. They are more likely to be attested in formal, literary or legal language, and the constructions with the corresponding finite verbs are usually preferred. They usually feature as subjects, objects or complements of prepositions. If present, the NP complement in the genitive case corresponds to the direct object of a transitive verb or the subject of an intransitive verb. Further examples illustrating these facts come from literary texts (22a) as well as legal expressions $(22 b):^{20}$

${ }^{20}$ The examples in (22b) come from an on-line Irish-English dictionary - http://www.englishirishdictionary.com/dictionary 
(22) a. Má bhodhrann siad sinn leis an bhfiafraí níl againn ach iadsan a bhodhradh leis an insint.

'If they bother (weary) us with inquiry we have no choice but to annoy them with talking.' (Ó Cadhlaigh 1940: 75 )

Ach feicim go bhfuil an cliseadh céanna ar an léamh go ginearálta.

'But I see that there is the very same decay of reading in general' (Ó Cearúil 1999: 110)

agus crith chos is lamh uirthi 'and the shaking of legs and hands upon her' (Gagnepain 1963: 302)

de réir bhualach phras an chloig 'according to quick striking of the clock' (Ó Cearúil 1999: 107)

B'in deireadh ghiniúna na gine. 'It was the end of begetting of children.' (Ó Cearúil 1999: 108)

Bhí titim na hoíche ann. 'There was falling of the night. The night was falling.' (Ó Cadhlaigh 1940: 74 )

$i$ dteacht Íosa Chríost ár dtíorna 'in the coming of Jesus Christ our Lord' (Yvan 1955: 9)

b. an tAcht um Rialú Madraí, maidir le beostoc a chosaint óna gciapadh ag madraí

'Control of Dogs Act, for the protection of livestock from worrying by dogs (lit. from their worrying by dogs)'

Folaíonn cleachtadh na míochaine cleachtadh na máinliachta, an chnáimhseachais agus araíonachtaí eile na míochaine agus forléireofar liachleachtóir dá réir sin

'Practice of medicine includes practice of surgery, midwifery and other disciplines of medicine and medical practitioner shall be construed accordingly' caighdeáin íosta maidir le cáiliú náisiúnach tríu tíortha mar dhídeanaithe 'minimum standards with respect to the qualification of nationals of third countries as refugees'

troscán atá déanta nó oiriúnaithe d'imirt cluichí nó cleachtadh coirp, gléasanna ceoil, ornáidí, lampaí

'furniture constructed or adapted for the playing of games or for physical exercise (lit. exercising of the body), musical instruments, ornaments, lamps' fior-riachtanach do mhaireachtáil an phobail i dtrathanna mórghanntanais solathair 'indispensable for the survival of the population in times of serious supply shortages'

In sum: there are Complex Event nominals in Irish. A question that remains is: are there any countable/singular nominalisations?

\subsection{De-verbal nouns (Countable nominalisations)}

Some nominalisations seem not to exactly mirror the subcategorisation frames of the related verbs. Participants representing direct arguments of the underlying verbs may be denoted by noun phrases dominated by lexically specialised prepositions. For example, Ó Siadhail (1989: 306) points to 
the spread of prepositional phrases with ar preceding the complements of nominalisations which correspond to objects of verbs.

a. Do rug gach comharsa abhaile leis a insint féin ar an scéal. PRT bring-past every neighbour home with-him his tell-VN self on the story 'Every neighbour brought home his own version of the story.'

(Ó Cadhlaigh 1940: 75 )

Cf. D’inis gach comharsa an scéal. tell-past every neighbour the story 'Every neighbour told the story.'

Cf. Tá dhá insint ar an scéal. is two tell-VN on the story 'There are two versions of the story. ${ }^{21}$

b. mo chéad léamh ar Bhullaí Mhártain 'my first reading of Bhullaí Mhártain' (Ó Cearúil 1999: 106)

In the following example we can observe that the NP corresponding to the direct object of the verb is preceded by the preposition de 'from', and that the external argument inherited from the verbal base is realised syntactically by a noun phrase occurring as a genitive.

\section{Tá fágaint na mairnéalach den leac seo}

ar na hiontaisi

is leave-VN the sailors-gen. from-the rock this among the wonders

$$
\text { is mó atá i stair an Bhlascaoid. }
$$

greatest which-are in-the history the Blasket-gen.

'The departure of the sailors from this rock is one of the strangest things in the history of the Blasket.' (Ó Criomhthain 1997: 140)

\section{Cf. D’fhág na mairnéalaigh an leac. leave-past the sailors the rock 'The sailors left the rock.'}

The subject of the verb can be realised by the $a g$-phrase but the direct object is not in the genitive as with uncountables but is introduced by $a r$.

Caoinim ... an fáil ar bhás atá ag gach a maireann. lament-1stsg. the get-VN on death is at every that live-present.ind. 'I lament finding of death by everything that lives.' (Ó Cearúil 1999: 110)

${ }^{21}$ This example comes from an on-line dictionary (http://www.englishirishdictionary.com/ dictionary). A similar sentence can be found in (Ó Dónaill 1977: 713) - Bíonn dhá insint ar scéal 'There are two ways of telling a story, two sides to an argument'. 
There exist many more countable nominalisations than appears at first sight. They can be found in constructions with semantically light verbs (LVC). ${ }^{22}$ The inventory of verbs utilised in Irish LVCs includes among others: déan 'do', tabhair 'give', lig 'let', faigh 'get', bain 'take, extract', cuir 'put'. The construction in question imposes a telic reading upon the situation denoted by the verb acting as the base for the $\mathrm{VN}$ or is used to achieve a partitive or singulative effect (Ó Siadhail 1989: 307, Wigger 2008).

If the VNs involved in complex predicates were verbs, the syntactic rules would have to be amended to account for the occurrence of typically nominal modifiers with verbs such as the definite article, possessives, demonstratives, NPs in the genitive case and adjectives as depicted below:

$$
\begin{aligned}
& \text { An teagasc a fuair mé i dtús mo shaoil } \\
& \text { the teach-VN that get-past I in the beginning my life-gen. } \\
& \text { 'What I was taught to do in early life' (Ó Dónaill 1977: 1216) } \\
& \text { Bain do shásamh as. } \\
& \text { take-imper. your satisfy-VN out of-it } \\
& \text { 'Take what you want of it.' (Ó Dónaill 1977: 1035) } \\
& \text { An ndéanfaidh tú an damhsa seo liom? } \\
& \text { do-cond. you the dance-VN this with-me } \\
& \text { 'May I have this dance?' (Ó Dónaill 1977: 367) } \\
& \text { snámh an duine mharaibh a dhéanamh } \\
& \text { swim-VN the man-gen. dead PRT do-VN } \\
& \text { 'to float on one's back' (Ó Dónaill 1977: 1123) } \\
& \text { Rinne sé diol maith. } \\
& \text { do-past he sell-VN good } \\
& \text { 'He made a good sale.' (Ó Dónaill 1977: 410) }
\end{aligned}
$$

The quantifying expressions with which they co-occur point to their countability. These include the numeral amháin 'one' and eile which combines with a singular countable noun to mean 'another'.

$$
\begin{aligned}
& \text { Thug mé féachaint amháin orthu. } \\
& \text { give-past I look-VN one on-them } \\
& \text { 'I took a glance at them.' (Ó Dónaill 1977: 522) } \\
& \text { Tabhair téamh beag eile don bhainne. } \\
& \text { give-imper.-you warm-VN small another to-the milk } \\
& \text { 'Warm the milk a little more.' (Ó Dónaill 1977: 1217) }
\end{aligned}
$$

\footnotetext{
${ }^{22}$ A detailed analysis of the semantics, the nominal status of VN in LVCs is available in Bloch-Trojnar (2006, 2009).
} 
There are certain modifiers that signal that a bounded object ${ }^{23}$ is implied such as cuid 'part, share, portion', éigin 'some' or ordinal numbers as exemplified below:

(28) Déan do chuid oibre.

do-imper. your share work-VN-gen.

'Get on with your work.' (Ó Dónaill 1977: 918)

Ba cheart duit seoladh éigin a dhéanamh dúinn.

Is right to-you direct-VN some PRT do-VN to-us

'You should give us some guidance' (i.e. directions) (Ó Dónaill 1977: 1088)

An chéad sá a rinne sé.

the first thrust-VN that make-past he

'The first dart he made' (Ó Dónaill 1977: 1018)

The tenability of this analysis could be confirmed by examples in which VNs in LVCs take overt plural morphology as in:

(29) crith 'tremble' - crith, gen.sg. creatha, pl. creathanna

Bhí sé ag cur creathanna fuachta de. 'There were cold shivers passing though him.' (Ó Dónaill 1977: 319)

In order to do justice to the facts of the language we need to admit that such cases are few and far between and their status is dubious. Consider two other examples:

(30) cathaigh 'battle, fight, tempt' - cathú, gen.sg. cathaithe, pl. cathuithe cathú, cathuithe a chur ar dhuine 'to tempt s.o.' (Ó Dónaill 1977: 198)

ordaigh 'order' - ordú, gen.sg. ordaithe, pl. orduithe

ag cur orduithe ar dhuine 'ordering s.o. about' (Ó Dónaill 1977: 934)

The verb cathaigh is obsolete, including the $\mathrm{VN}$ and in synchronic terms cathú is perceived as underived. As far as ordaigh is concerned, like in English, there seems to be a difference between tugaim ordú do dhuine vs. ag cur orduithe ar dhuine, the latter being a lexicalised phrase (note the different preposition) meaning 'give somebody orders, order somebody about'.

${ }^{23}$ In the first two examples a limited section of a process is extracted and in the third one the action in its entirety is brought to the foreground of attention - the first instantiation presupposes that there could be second, third etc. Quantification processes of bounding and debounding in the nominal and verbal domain are laid out in detail in Brinton (1998) and Willim (2006). 
This, however, needs not invalidate our proposal. There is a fair number of examples with modifiers which make it clear that more than one instance or occurrence of a given action is referred to. They include: cardinal numbers and quantifiers such as iomaí 'many', cúpla 'a few' and mórán 'many'. ${ }^{24}$

(31) Chuir sé na seacht seachaint orm.

put-past he the seven guard-VN on-me

'He warned me (repeatedly) to be careful.' (Ó Dónaill 1977: 1070)

Is iomaí cardáil a rinneadh ar an scéal sin.

is many wool-carding-VN PRT was-done on the story that

'That story has often been sifted, debated.' (Ó Dónaill 1977: 191)

Is iomaí tiortáil a fuair sé ina lá.

is many knock about-VN PRT get-past he in-his day

'He took many a knock in his day.' (Ó Dónaill 1977: 1240)

Déan cúpla scrabhadh leis an scian air.

do-imper. a few scratch-VN with the knife on-it

'Score it a few times with a knife.' (Ó Dónaill 1977: 1063)

Being morphologically singular, as expected, de-verbal nominals are not as good as their verbal counterparts in preserving the subcategorisation of the base verb.

Verb
duine a dhíotáil
'indict s.o.'
rud a fhógairt
'declare, proclaim sth'
rud a fhoghlaim
'learn sth'
capall a ghiollacht
'to lead a horse'

VN in LVC

díotáil a dhéanamh ar dhuine 'to indict, lay an indictment against s.o.' (Ó Dónaill 1977: 414)

fógairt a dhéanamh ar rud 'announce sth' (Ó Dónaill 1977: 558)

foghlaim a dhéanamh ar rud 'learn, study sth' (Ó Dónaill 1977: 559) giollacht a dhéanamh ar chapall 'to lead a horse' (Ó Dónaill 1977: 634)

Furthermore, only a fraction of modifying NPs in the genitive case corresponds to the object of a transitive verb, as in:

${ }^{24}$ It should be borne in mind that cardinals are followed as a rule by the singular form of the noun. The quantifier iomai ' many' can be followed only by singular countable nouns, e.g. is iomaí lá a bhí mé ann 'many a day I was there'. 
(33) diol fiach a thabhairt do dhuine

'repay a debt to s.o.' (Ó Dónaill 1977: 410)

Rinneadh iomlua sithe earthu.

'Peace was proposed between them.' (Ó Dónaill 1977: 721)

Bhain mé seachaint an tí as.

'I kept him away from the house.' (Ó Dónaill 1977: 1070)

Most often they realise syntactically LCS participants which bear circumstantial semantic functions, such as manner, instrument, place and time as depicted below.

a. Manner:

Ná tabhair roinnt an chommittee air! not give-imper. divide-VN the committee-gen. on-it

'Don't divide it as the committee would!' (Ó Siadhail 1989: 307)

Tugadh fiach an bhacaigh dom. 'I was chased like a beggar.' (Ó Dónaill 1977: 538)

b. Instrument:

Rinneadh lot scine air.

do-past-pass.-impers. injure-VN knife-gen. on-him

'He was wounded with a knife.' (Ó Dónaill 1977: 803)

Chuir siad radadh cloch linn. 'They showered us with stones.' (Ó Dónaill 1977: 979)

Thug sé cúnamh an dá lámh dom. 'He helped me with both hands, most willingly.' (Ó Dónaill 1977: 355)

gearradh teanga a thabhairt do dhuine 'to give s.o. a severe scolding'(Ó Dónaill 1977: 624)

Cuir coipeadh maith den ghallúnach orthú . 'Lather them well with soap.'(Ó Dónaill 1977: 270)

Thug sí cuimilt den teanga dó. 'She gave him a bit of a scolding.'

(Ó Dónaill 1977: 340)

c. Temporal:

máirseáil lae a dhéanamh ‘do a day’s march’ (Ó Dónaill 1977: 820)

d. Place:

Thug mé ithe na páirce dóibh. 'I let them graze in the field.' (Ó

Dónaill 1977: 734)

In other cases we seem to have to do with compound expressions due to the generic reference of the following NP (cf. Doyle 1996). In that case an $\mathrm{LVC}$ in question is made up of $\mathrm{LV}+\mathrm{N}$ rather than $\mathrm{LV}+\mathrm{VN}$. 
a. Blaiseadh béil ní bhfuair mé.

taste-VN mouth-gen. not get-past I

'Not a bite / a sup did I get.' (Ó Dónaill 1977: 113)

b. Fuair sé goin ghréine. 'He got sunstroke' (Ó Dónaill 1977: 658)

Cuirfeadh sé casadh aigne ort. 'It would nauseate you.' (Ó Dónaill

1977: 195)

crá croí a fháil 'to suffer heartbreak / be overwhelmed with sorrow' (Ó Dónaill 1977: 306)

leagan/ silleadh súl a thabhairt ar rud 'look, glance, cast an eye over sth' (Ó Dónaill 1977: 760/1093)

seachadadh láimhe a thabhairt do dhuine 'give s.o. a tip' (Ó

Dónaill 1977: 1069)

To round up: in contradistinction to their English opposite numbers (have a go, take a look, make a throw, do a check up or give a smile), LVCs in Irish require a morphologically singular de-verbal noun. In resisting pluralisation, Irish de-verbal nouns resemble their Polish counterparts. The use with light verbs is much more regular and categorial than that of what we call actional, non-countable nominalisations, discussed previously. Unlike both English and Polish the endings for both nominalisation types are the same.

\section{Conclusion}

Let us summarise the tentative conclusions we have reached in the course of our discussion. Firstly, there are grounds to assume that in Irish, English and Polish there are two nominalising rules, differentiating derivatives in terms of their affinity to source verbs. They can be referred to as Nomina Verbalia (verbal nominalisations) and Nomina De-verbalia (deverbal nominalisations). The former are closely tied up with related verbs and mirror exactly their PAS and they are in all likelihood uncountable, i.e. number distinctions are irrelevant. The latter inherit LCS participants of corresponding verbs but may realise them with the help of prepositions and are morphologically singular. Secondly, it appears that only in English actional [+Singular] nouns can be in the plural. We have also observed that in Irish and English, unlike in Polish, which expresses aspect morphologically, [+Singular] derivatives display a telic reading. Furthermore, in English and Polish there are different morphological markers for each category, unlike in Irish where this surface distinction is neutralised. Finally, 
in all three languages regularly formed nominals are subject to lexicalisation, which may lead to concrete meanings and may result in countable nouns capable of pluralising. ${ }^{25}$

\section{References}

BAUER, L., 1983: English Word Formation, Cambridge.

BEARD, R., 1976: 'A semantically based model of a generative lexical WordFormation Rule for Russian adjectives', in: Language 52, 108-120.

BEARD, R., 1982: 'Plural as a lexical derivation', in: Glossa 16, 133-48.

BEARD, R., 1995: Lexeme Morpheme Base Morphology, Albany, NY.

BeARD, R. \& VolPe, M., 2005: 'Lexeme-Morpheme Base Morphology', in: Štekauer, P. \& Lieber, R., eds., Handbook of Word-Formation, Dordrecht, 189-206.

Bloch-Trojnar, M., 2006: Polyfunctionality in Morphology. A Study of Verbal Nouns in Modern Irish, Lublin.

Bloch-TrojnaR, M., 2007: 'Even more remarks on nominalisation', in: Stalmaszczyk, P. \& Witczak-Plisiecka, I., eds., PASE Studies in Linguistics, Łódź, 47-56.

Bloch-TrojnaR, M., 2008: 'The morphology of verbal nouns in Modern Irish', in: Éigse 36, 63-81.

Bloch-TrojnaR, M., 2009: 'On the nominal status of VNs in light verb constructions in Modern Irish', in: Kuźniak, M \& Rozwadowska, B., eds., PASE Papers 2008. Vol 1. Studies in Language and Methodology of Teaching Foreign Languages, Wrocław, 25-33.

Brinton, L., 1988: The Development of English Aspectual Systems, Cambridge.

BRINTON, L., 1998: 'Aspectuality and countability: a cross-categorial analogy', in: English Language and Linguistics 2, 37-63.

Cetnarowska, B., 1993: The Syntax, Semantics and Derivation of Bare Nominalisations in English, Katowice.

Cномsку, N., 1970: 'Remarks on nominalisation', in: Roderick, J. \& Rosenbaum, P., eds., Readings in English Transformational Grammar, Waltham, 189-221.

DE BHALDRATTHE, T., 1953: Gaeilge Chois Fhairrge: An Deilbhiocht, Baile Átha Cliath.

DE BHALDRAITHE, T., 1959: English - Irish Dictionary, Baile Átha Cliath.

De BHAldRaItHe, T., 1985: Foirsiún Focal as Gaillimh, Baile Átha Cliath.

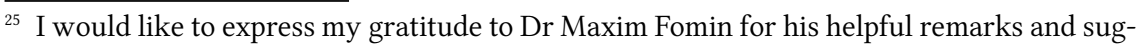
gestions, which have led to important clarifications and improvements in this paper. 
Di Sciullo, A. M. \& Williams, E., 1987: On the Definition of Word, Cambridge, Mass.

DinNEEn, P. S., 1927: Irish-English Dictionary, Dublin.

Doyle, A., 1996: 'Compounds and syntactic phrases in Modern Irish', in: Studia Anglica Posnaniensia 30, 83-96.

Doyle, A., 2002: Covert and Overt Pronominals in Irish, Lublin.

Duffield, N., 1995: Particles and Projections in Irish Syntax, Dordrecht.

GagnePain, J., 1963: La Syntaxe du Nom Verbal dans les Langues Celtiques, Paris.

Grimshaw, J., 1990: Argument Structure, Cambridge, Mass.

Grzegorczykowa, R., Laskowski, R. \& Wróbel, H., EDS., 1999: Gramatyka Wspótczesnego fęzyka Polskiego, Warszawa.

Higginbotham, J., 1985: 'On semantics', in: Linguistic Inquiry 16, 547-593.

http://www.englishirishdictionary.com/dictionary

KoptJevskaja-TAmM, M., 1993: Nominalisations, London.

Malicka-Kleparska, A., 1988: Rules and Lexicalisations. Selected English Nominals, Lublin.

Marchand, H., 1969: The Categories and Types of Present-day English Wordformation. A Synchronic-Diachronic Approach, München.

McCloskey, J., 1983: ‘A VP in a VSO language?’, in: Gazdar, G., Klein, E. \& Pullum, G., eds., Order, Concord and Constituency, Dordrecht, 9-55.

Ó CAdHlaigh, C., 1940: Gnás na Gaedhilge, Baile Átha Cliath.

Ó Criomhthain, T., 1997: Bloghanna ón mBlascaod, Baile Átha Cliath.

Ó Cearúll, M., ED., 2000: An Aimsir Óg, Baile Átha Cliath.

Ó DónAILl, N., 1977: Foclóir Gaeilge-Béarla, Baile Átha Cliath.

Ó hAirt, D., 1988: Díolaim Dhéiseach, Baile Átha Cliath.

Ó hAnluain, L. A., 1999: Graiméar Gaeilge na mBráithre Críostaí, Baile Átha Cliath.

Ó SiAdHAIL, M., 1989: Modern Irish. Grammatical Structure and Dialectal Variation, Cambridge.

Puzynina, J., 1969: Nazwy Czynności we Wspótczesnym Języku Polskim. (Stowotwórstwo, Semantyka, Składnia), Warszawa.

Quirk, R., Greenbaum, S., Leech, G. \& Svartvik, J., 1985: A Comprehensive Grammar of the English Language, London and New York.

RANDALL, J., 1984: 'Grammatical information in Word Structure', in: Quaderni di Semantica 5, 313-330.

RANDAll, J., 1984: 'Thematic structure and inheritance', in: Quaderni di Semantica 5, 92-110.

Randall, J., 1988: 'Inheritance', in: Wilkins, W., ed., Thematic Relations: Syntax and Semantics, San Diego, 129-146. 
RoEPER, T., 1987: 'Implicit arguments and the head-complement relation', in: Linguistic Inquiry 18, 267-310.

Rozwadowska, B., 1997: Towards a Unified Theory of Nominalisations. External and Internal Eventualities, Wrocław.

SZYMANEK, B., 1989: Introduction to Morphological Analysis, Warszawa.

SZYMAŃSKA, I. \& ŚPIEWAK, G., 1994: 'Some remarks on the predicate-argument structure of Polish and English nominalisations', in: Gussmann, E. \& Kardela, H., eds., Focus on Language, Lublin, 193-205.

Walíśsa de HACKBeil, H., 1984: 'On two types of derived nominals', in: Testen D., Mishra, V. and Drogo, J., eds., Papers from the Parasession on Lexical Semantics, Chicago, 308-332.

WigGeR, A., 2008: 'Advances in the lexicography of Modern Irish verbs', in: Bloch-Rozmej, A., ed., Issues in Celtic Linguistics, Lublin, 233-50.

Williams, E., 1981: 'Argument structure and morphology', in: Linguistic Review 1, 81-114.

Willim, E., 2006: Event, Individuation, and Countability. A Study with Special Reference to English and Polish, Kraków.

Yvan, A., 1955: Trompa na bhFlaitheas, in: O’Rahilly, C., ed., Baile Átha Cliath.

\section{Odabrani vidovi sintakse i semantike odglagolskih imenica u engleskom, poljskom i irskom}

\section{Sažetak}

Imajući na umu formalnu i funkcionalnu složenost kategorije glagolskih imenica u irskom, ne iznenađuje što je i dalje predmetom intenzivnih proučavanja. Puno se pisalo o sintaksi glagolskih imenica, tj. o glagolskim imenicama unutar participskih i infinitivnih konstrukcija. Lingvisti tako žustro raspravljaju o tome treba li ih smatrati imenicama ili glagolima (npr. McCloskey (1983) i Duffield (1995) predstavnici su suprotstavljenih mišljenja) da je zanemareno područje odglagolskih imenica. Ovaj rad zamišljen je kao skroman pokušaj da se popravi stanje i da se predstave neki vidovi njihove sintakse, semantike i formalne tvorbe. U tijeku rasprave pokušat ćemo odrediti može li se proces binarne opreke prema rezultativnim imenicama (koji se razmatra u svim studijama o poimeničavanju) pronaći jednako u imenicama izvedenima od prijelaznih i od neprijelaznih glago- 
la. Većina studija o poimeničavanju (iznimka je Rozwadowska (1997)) zanemaruju ili izričito isključuju neprijelazne glagole. Razmatrat ćemo i dva moguća pogleda na proces poimeničenja, tj. treba li rezultativne imenice smatrati ishodom semantičkog pomaka (kao u npr. Malicka-Kleparska (1988)) ili ishodom odvojenih derivacijskih procesa koji daju brojive imenice (usp. sličnu analizu za engleski u Bloch-Trojnar (2007)). Sintaktičke i semantičke osobine imenica u irskom usporedit ćemo s njihovim poljskim i engleskim odgovarajućim parom. Naposljetku, razmotrit ćemo i njihove morfofonološke osobine. Tvrdimo da je model LMBM (Beard (1995)), koji razdvaja formalne i sintaktičko-semantičke strane derivacije, najupotrebljiviji za obradbu ovih podataka.

Ključne riječi: poimenčenje radnje, glagolska imenica u irskom, konstrukcija sa semantički ispražnjenim glagolom

Key words: action nominalisation, verbal noun in Irish, light verb construction 